\section{Eponyms in medicine}

After reading an excellent article titled "Origen de algunos epónimos empleados en pediatría derivados de la literatura" ("Origin of certain eponyms used in pediatrics derived from literature") by Alejandro F. Donoso, M.D. and Daniela S. Arriagada, M.D., ${ }^{1}$ I would like to share the following considerations on this topic.

First of all, eponyms, and in particular those derived from the literature, not only embellish medical language but also evoke images, so they are capable of bringing together our own symbol-related ideas; i.e., they may be capable of communicating, in a few words, something that would require full sentences in scientific language, thus streamlining medical thinking. ${ }^{2}$ For example, it is more functional to discuss a "positive Godet's sign" than an "edema caused by the accumulation of water and sodium in the skin, which leaves an imprint after pressing it and may be the result of an imbalance between hydrostatic and oncotic pressure in the intravascular and interstitial compartments and/or an increased capillary permeability, induced by local (e.g., venous obstruction, etc.) or systemic causes (e.g., heart, kidney or liver failure)".

Second of all, eponyms may sometimes account for the recognition of scientists or artists who have made significant contributions to medicine. This attitude is not only a beau geste towards our illustrious predecessors but a reminder that the medical discipline is not a finished product or a spontaneous outcome but the result of a knowledge process that required, and still requires, a collective contribution. ${ }^{3}$

In the third place, eponyms frequently build a bridge that connects medicine and the rest of culture. Such bridge facilitates the interdisciplinary exchange of ideas from which new hypotheses and scientific theories that could be used in the medical field may emerge. ${ }^{4}$
Finally, it should be noted that, over time, some eponyms may become anachronistic because they evoke images that lack current meaning (e.g., proconsular neck) or refer to concepts that are now outdated (e.g., Lombrosian face); therefore, these could be replaced with new eponyms capable of evoking a current concept or simply be abandoned.

To sum up, eponyms make the medical language beautiful and effective, pay tribute to the shapers of medical knowledge, and establish a bond with the rest of culture. Notwithstanding this, eponyms may need to renew or will otherwise become obsolete.

Key words: eponyms, medicine, symbol.

Carlos G. Musso, M.D., PhD. Department of Physiology. Instituto Universitario del Hospital Italiano de Buenos Aires, Argentina

http:/ / dx.doi.org/10.5546/aap.2019.eng.142

To cite: Musso CG. Eponyms in medicine. Arch Argent Pediatr 2019;117(3):142.

\section{REFERENCES}

1. Donoso FA, Arriagada SD. Origen de algunos epónimos empleados en pediatría derivados de la literatura. Arch Argent Pediatr. 2019;117(3):188-94

2. Musso CG, Enz PA, Werbin E. El símbolo y su función terapéutica: en busca de sus fundamentos científicos. Arch Argent Pediatr. 2016; 114(5):403-4.

3. Lehrer J. Proust y la Neurociencia: una visión única de ocho artistas fundamentales de la modernidad. Barcelona: Paidos; 2010.

4. Root-Berstein R, Root-Berstein M.El secreto dela creatividad. Barcelona: Kairos; 2002. 